\title{
Maternal Methyl Donor Supplementation during Gestation Counteracts the Bisphenol A-Induced Impairment of Intestinal Morphology, Disaccharidase Activity, and Nutrient Transporters Gene Expression in Newborn and Weaning Pigs
}

\author{
Hong Liu, Jun Wang, Daolin Mou, Lianqiang Che, Zhengfeng Fang, Bin Feng, Yan Lin, \\ Shengyu Xu, Jian Li and De Wu* \\ Institute of Animal Nutrition, Sichuan Agricultural University, No. 211, Huimin Road, Wenjiang District, \\ Chengdu 611130, China; dkbshliuhong@sina.com (H.L.); wjss1987@163.com (J.W.); \\ md119920101@foxmail.com (D.M.); clianqiang@hotmail.com (L.C.); fangzhengfeng@hotmail.com (Z.F.); \\ fengb123d@163.com (B.F.); able588@163.com (Y.L.); shengyu_x@hotmail.com (S.X.); lijian522@hotmail.com (J.L.) \\ * Correspondence: sow_nutrition@sina.com; Tel.: +86-835-2885-107
}

Received: 20 January 2017; Accepted: 19 April 2017; Published: 26 April 2017

\begin{abstract}
This study was conducted to explore whether exposure to bisphenol A (BPA) during pregnancy could change intestinal digestion and absorption function in offspring using pigs as a model, and whether methyl donor (MET) could counteract the BPA-induced impacts. Fifty Landrace $\times$ Yorkshire sows were divided into four dietary groups throughout gestation: control $\operatorname{diet}(\mathrm{CON})$; control diet supplemented with BPA $(50 \mathrm{mg} / \mathrm{kg})$; control diet supplemented with MET ( $3 \mathrm{~g} / \mathrm{kg}$ betaine, $400 \mathrm{mg} / \mathrm{kg}$ choline, $150 \mu \mathrm{g} / \mathrm{kg}$ vitamin B12, and $15 \mathrm{mg} / \mathrm{kg}$ folic acid); and control diet with BPA and MET supplementation (BPA + MET). Intestine samples were collected from pigs' offspring at birth and weaning. Maternal BPA exposure during pregnancy significantly reduced the ratio of jejunum villus height to crypt depth, decreased the jejunum sucrase activity, down-regulated the mRNA expression of jejunum peptide transporter 1 (Pept1) and DNA methyl transferase 3a (DNMT3a), and decreased the DNA methylation level of jejunum Pept1 in offspring $(p<0.05)$. Maternal MET supplementation significantly raised the ratio of villus height to crypt depth in jejunum and ileum, improved the jejunum lactase activity, up-regulated the mRNA expression of jejunum Pept1, lactase (LCT), DNMT1, DNMT3a, and methylenetetrahydrofolate reductase (MTHFR), and increased the DNA methylation level of jejunum Pept1 in offspring $(p<0.05)$. However, the ratio of jejunum villus height to crypt depth was higher in BPA + MET treatment compared with CON and BPA treatment $(p<0.05)$. Meanwhile, there was no difference in the jejunum sucrase activity, the mRNA expression of jejunum Pept1 and DNMT3a, and the DNA methylation level of jejunum Pept1 between CON and BPA + MET treatment. These results indicated that maternal exposure to BPA during gestation might suppress offspring's intestinal digestion and absorption function, whereas supplementation of MET could counteract these damages, which might be associated with DNA methylation.
\end{abstract}

Keywords: bisphenol A; methyl donor; maternal; offspring; intestine

\section{Introduction}

Bisphenol A (BPA) is a kind of industrial chemical compound widely used in the manufacturing of polycarbonate plastics, such as baby bottles, infant tableware and the epoxy resin lining of beverage or food cans $[1,2]$. Exposure to BPA is a threat to human health according to the findings of its widely 
negative effects in animal studies [3]. As the prevalent existence of BPA in the environment as well as the detection in urine, plasma and placenta tissue of pregnant women [4], increasing evidence has shown that prenatal BPA exposure increased the risk of situations such as immune dysregulation, productive disorders, and disordered sexual differentiation $[5,6]$. To our knowledge, growth and health throughout the life cycle of mammals are closely related to their intestinal function, but the impact of gestational BPA exposure on the intestinal digestion and absorption function remains an unexplored endpoint.

A growing body of research shows that a broad range of adverse effects induced by BPA are linked to epigenetic modifications, such as DNA methylation $[7,8]$. The first convincing study on agouti confirmed that maternal BPA exposure led to DNA methylation status and expression of specific altered genes in offspring [9]. An in vivo study has shown that BPA exposure decreased the global DNA methylation of oocyte, likely through decreased DNA methyltransferases [10]. Later evidence has demonstrated that gestational exposure to BPA decreased the global DNA methylation or methylation at the promoter in special genes in the brain, liver, and ovary tissue of the offspring [11,12]. Importantly, abnormal DNA methylation is associated with embryonic death, impaired fetal development, cancer and diseases of the brain, liver, kidneys and heart [13]. Therefore, researchers hypothesized that if BPA-induced intestinal function changes as speculated, it may be related to DNA methylation. DNA methylation is highly dependent on one-carbon metabolism, which involves sources of methyl groups such as choline, betaine and folate, as well as co-factors, for instance, vitamin B12 [14,15]. Therefore, methyl donor (MET) and co-factors from diet are crucial for normal DNA methylation. In mouse models, maternal diets containing much higher amounts of MET promoted DNA hypermethylation and led to long-term changes in gene expression and altered phenotypes in the offspring [16]. Even so, studies regarding the influence of maternal MET supplementation on intestine function in offspring are few. In this study, the effect of maternal MET supplementation was explored on intestinal function in offspring.

It is interesting that early developmental exposure to BPA can change offspring phenotype, stably altering the epigenome, but is counteracted by maternal MET supplements [9]. Therefore, this study explored the effects of maternal MET or BPA supplementation on intestinal function in offspring, and observed whether the effects last from birth to weaning.

\section{Materials and Methods}

\subsection{Animals and Experimental Design}

The experimental procedures were approved by the Animal Care and Use Committee of Animal Nutrition Institute, Sichuan Agriculture University, and followed the current laws of animal protection (Ethic Approval Code: SCAUAC201408-3). A total of fifty 3-5 parity Landrace $\times$ Yorkshire sows were artificially inseminated, then weighed $(211.63 \pm 2.65 \mathrm{~kg})$, and randomly allocated to four groups at day 1 of gestation. Pregnant sows were fed one of the four diets: control diet (CON, $n=13)$; control diet + BPA $(n=13)$; control diet + MET $(n=12)$; and both BPA and MET supplementation in control diet (BPA $+\mathrm{MET}, n=12)$. The control diet was the basal diet during pregnancy (Table 1 ), which completely met the recommendations of the National Research Council 2012 (NRC 2012), and nutritional values referenced from Chinese feed ingredients data (2013). The basal diet during pregnancy contained $3.05 \mathrm{Mcal}$ digestible energy (DE) $/ \mathrm{kg}$ diet and $14 \%$ crude protein. The BPA diet was supplemented with $50 \mathrm{mg} / \mathrm{kg}$ diet of BPA (Sigma Aldrich, St. Louis, MO, USA). MET supplementation premix consisted of $3 \mathrm{~g} / \mathrm{kg}$ diet of betaine (98\% betaine hydrochlorides; Hangzhou Healthy Husbandry Sci-tech Co., Ltd., Hangzhou, China), $400 \mathrm{mg} / \mathrm{kg}$ diet of choline (50\% choline chloride; Shandong Enbei Group Ltd., Shandong, China), $15 \mathrm{mg} / \mathrm{kg}$ diet of folate (Sigma Aldrich, St. Louis, MO, USA) and $150 \mu \mathrm{g} / \mathrm{kg}$ diet of vitamin B12 (Sigma Aldrich, St. Louis, MO, USA). The basal diet consisted of $482 \mathrm{~g} / \mathrm{kg}$ diet of betaine, $1250 \mathrm{mg} / \mathrm{kg}$ diet of choline, $1.3 \mathrm{mg} / \mathrm{kg}$ diet of folate, and $15 \mu \mathrm{g} / \mathrm{kg}$ diet of vitamin B12, which were calculated values and met the recommended levels of choline, folate, and vitamin B12 
(NRC, 2012). During lactation, all the sows were offered the same standard lactation diet, which contained 3.35 Mcal DE $/ \mathrm{kg}$ diet and 17.5\% crude protein. Lactation lasted 28 days. The experiment began with 56 sows -14 sows per treatment. Four sows were eliminated due to failure of gravidity, two sows were eliminated due to postpartum paralysis.

Table 1. Ingredients and nutrient composition of basal diets fed to sows throughout gestation and lactation.

\begin{tabular}{ccc}
\hline Item & Gestation & Lactation \\
\hline Ingredients $(\mathrm{g} / \mathrm{kg})$ & & \\
Corn & 636.15 & 629.00 \\
Soybean meal & 145.00 & 226.00 \\
Fish meal & & 25.00 \\
Soybean oil & 180.00 & 30.00 \\
Wheat bran & 0.80 & 50.00 \\
L-lysine.HCl (98\%) & & 2.70 \\
D-Methionine (98\%) & 11.10 & 1.10 \\
Calcium carbonate & 13.80 & 10.00 \\
Dicalcium phosphate & & 10.70 \\
Sodium bicarbonate & & 4.00 \\
Choline (50\%) & 3.00 & 1.00 \\
Salt & 10.15 & 4.00 \\
Total & 1000.00 & 6.50 \\
Vitamin and Mineral Premix * & & 1000.00 \\
Nutrient level ${ }^{\dagger}$ & 3.05 & \\
Digestible energy, Mcal/kg & 14.00 & 3.35 \\
Crude protein, \% & 0.69 & 17.50 \\
Total Lysine, $\%$ & 0.60 & 1.12 \\
Total calcium, \% & 0.80 & 0.80 \\
Total phosphorus, \% & 0.68 & 0.63 \\
\hline
\end{tabular}

\begin{abstract}
* Vitamin and Mineral mixture for gestation sows supplied the following amounts of vitamins $/ \mathrm{kg}$ and minerals $/ \mathrm{kg}$ of complete diet: 9100 IU vitamin A; 2600 IU vitamin D3; 80 IU vitamin E; $2.6 \mathrm{mg}$ vitamin B1; $6.5 \mathrm{mg}$ vitamin B2; $3.9 \mathrm{mg}$ vitamin B6; $15 \mu \mathrm{g}$ vitamin B12; $26 \mathrm{mg}$ niacin; $1.3 \mathrm{mg}$ folacin; $265 \mathrm{mg}$ choline; $120 \mathrm{mg}$ iron; $20 \mathrm{mg}$ copper; $120 \mathrm{mg}$ zinc; $30 \mathrm{mg}$ manganese; $0.3 \mathrm{mg}$ selenium; $0.3 \mathrm{mg}$ iodine; $0.2 \mathrm{mg}$ chromium. Vitamin and Mineral mixture for lactation sows supplied the following amounts of vitamins $/ \mathrm{kg}$ and minerals $/ \mathrm{kg}$ of complete diet: 17,500 IU vitamin A; $5000 \mathrm{IU}$ vitamin D3; $80 \mathrm{IU}$ vitamin $\mathrm{E} ; 5 \mathrm{mg}$ vitamin B1; $12.5 \mathrm{mg}$ vitamin B2; $7.5 \mathrm{mg}$ vitamin B6; $0.05 \mathrm{mg}$ vitamin B12; $50 \mathrm{mg}$ niacin; $25 \mathrm{mg}$ pantothenic acid; $2.5 \mathrm{mg}$ folacin; $120 \mathrm{mg}$ iron; $20 \mathrm{mg}$ copper; $120 \mathrm{mg}$ zinc; $30 \mathrm{mg}$ manganese; $0.3 \mathrm{mg}$ selenium; $0.3 \mathrm{mg}$ iodine; $0.2 \mathrm{mg}$ chromium. ${ }^{+}$The basal diet for gestation sows contained: $482 \mathrm{mg} / \mathrm{kg}$ betaine, $1.3 \mathrm{mg} / \mathrm{kg}$ folic acid, $15 \mu \mathrm{g} / \mathrm{kg}$ VB12 and $1250 \mathrm{mg} / \mathrm{kg}$ choline calculated according to the China Feed Database (2014).
\end{abstract}

\title{
2.2. The Dose of Methyl Donors and BPA
}

The criteria for the addition of doses of folic acid, betaine, choline and VB12 in this trial were designed to ensure the maximum potential reproduction of the sow and induce the reduction of homocysteine level in plasma. Previous studies found that dietary supplementation with $15 \mathrm{mg} / \mathrm{kg}$ of folic acid [17], $3 \mathrm{~g} / \mathrm{kg}$ of betaine [18], $1650 \mathrm{mg} / \mathrm{kg}$ choline [19,20] or $150 \mu \mathrm{g} / \mathrm{kg}$ VB12 [21] was effective in increasing sow litter size, and significantly reduced homocysteine levels in plasma.

The dose of bisphenol A added was $50 \mathrm{mg} / \mathrm{kg}$. Dolinoy (2007) [9] and other studies [8,22] in mice found that $50 \mathrm{mg} / \mathrm{kg}$ diet of BPA can successfully induce hypomethylation in a single gene or the entire organism. Therefore, in this article, the dose of BPA was calculated through the daily intake of unit weight of mice.

During gestation, all sows were individually fed their trial diets two times per day (i.e., 08:00 and 14:30 h): $2.28 \mathrm{~kg} /$ day diet and $2.72 \mathrm{~kg} /$ day diet on days 1-90 and days 91 to parturition, respectively. At day 107 of gestation, sows were moved to the farrowing rooms and individually penned. After parturition, all the sows were offered the diet three times per day (i.e., 08:00, 12:00, and 15:00 h), starting at $2.0 \mathrm{~kg} /$ day, then gradually increasing $1 \mathrm{~kg} /$ day until the sixth day ad libitum. Throughout the 
experiment, all animals were free to access water. The ambient temperature for sows was maintained at $20-25^{\circ} \mathrm{C}$. Heating light and pads were provided for sucking piglets and the temperature was maintained at $26-32{ }^{\circ} \mathrm{C}$, which gradually decreased with the increase of age.

\subsection{Sample Collection}

When the piglets were born and weaning, researchers recorded the body weight of each, then selected piglets to be slaughtered and sampled according to body weight (body weight of newborn and weaning pigs seen in Table S1). Each group of 12 newborn piglets without eating colostrum (respectively from 12 litters and close to the average body weight in each treatment group, six males and six females) were slaughtered (a total of 48). Similarly, each group of six weaning piglets deprived of food overnight (respectively from six litters and close to the average body weight in each treatment group, three males and three females) were slaughtered (a total of 24). Piglets were slaughtered by jugular puncture, and the entire intestine was removed as quickly as possible. The content of the intestine was cleaned rapidly and gently. The small intestine (SI) was measured for weight and length. The middle portion (approximately four centimeters) of every segment in the small intestine (duodenum, jejunum and ileum) was obtained and placed in liquid nitrogen, later stored at $-80{ }^{\circ} \mathrm{C}$ for subsequent analysis. In addition, approximately one centimeter of integral duodenum, jejunum and ileum tissue was cut out, and fixed with four percent paraformaldehyde for intestinal slice production and morphology observation. The intestinal mucosa of the remaining duodenum, jejunum, and ileum segment was obtained with a glass slide scraping, frozen in liquid nitrogen, and stored at $-80{ }^{\circ} \mathrm{C}$ for future analysis of intestinal enzyme activity.

\subsection{Analysis of Intestinal Morphology}

Intestinal tissue samples were fixed with $4 \%$ formaldehyde, dehydrated with ethanol (from low concentration to high concentration up to $100 \%$ ), and then embedded in transparent paraffin and sliced. All tissue sections $(5 \mu \mathrm{m})$ were stained with hematoxylin and eosin $(\mathrm{HE})$, and mounted with gum. The slice images were captured at the magnification of $100 \times$ using an Olympus BX51 microscope equipped with a DP70 digital camera (Olympus, Tokyo, Japan). Crypt depth $(\mu \mathrm{m})$ and villus length $(\mu \mathrm{m})$ were measured with Image-Pro Plus 6.0 software (Media Cybernetics, Bethesda, Rockville, MD, USA). At least eight pairs of villus and crypt were observed in each slice; the average was the final value.

\subsection{Analysis of Intestinal Enzyme Activity}

The activity of intestinal lactase, maltase, and sucrase was measured. After thawing, 0.2-0.5 g of mucosa samples was homogenized according to the weight of intestine mucosa (g): volume of physiological saline pre-cooled on ice $(\mathrm{mL})=1: 9$, and centrifuged at $2500 \mathrm{r} / \mathrm{min}$ for $10 \mathrm{~min}$. The supernatant was used to measure activity. Before measurement, a pre-test was necessary for the optimal reaction condition. For instance, the appropriate reaction concentration of samples. The activity of disaccharide was measured strictly in accordance with the manufacturer's instructions for the kit (Jiancheng Bioengineering Ltd., Nanjing, China).

\subsection{RT-PCR Analysis}

Jejunum samples stored in a $-80{ }^{\circ} \mathrm{C}$ freezer were ground to powder with a mortar, adding liquid nitrogen continually. A 50-100 mg powder sample was put in an eppendorf tube containing $1 \mathrm{~mL}$ TRIzol (Invitrogen, Carlsbad, CA, USA), shaken up and down so as to completely dissolve the powder. Total RNA was extracted with TRIzol. RNA quality was detected by means of electrophoresis with $1.0 \%$ agarose gel at low temperature, $80 \mathrm{~V}$ for $25 \mathrm{~min}$, observing the picture under ultraviolet light. The strips should be clear and complete without smearing. The absorbance of RNA solution at wavelengths of $260 \mathrm{~nm}$ and $280 \mathrm{~nm}$ was measured by scanning spectrophotometer (Beckman DU-800, Beckman Coulter Inc., Brea, CA, USA); resulting in optical density (OD) $260 / \mathrm{OD}_{280}$ ranging 1.8-2.0. The concentration of RNA solution was confirmed by nucleic-acid/protein analyzer (Beckman DU-800) to 
determine the required amount in the next reverse transcription. After that, cDNA was synthesized with a reverse transcription (RT) kit (TaKaRa Biotechnology, Dalian, China), according to the manufacturer's instructions. The cDNA can be stored at $-20{ }^{\circ} \mathrm{C}$ for later relative quantification by polymerase chain reaction (PCR) or immediately used. Real-time PCR was performed with the synergy brands (SYBR) green mix system (catalogue no. RR820A: TaKaRa Biotechnology, Dalian, China) by ABI-7900HT instrument (Applied Bio Systems, Foster City, CA, USA). Ten microliters of mixed system (5 $\mu$ L SYBR Green Super mix, $1 \mu \mathrm{L}$ upstream primer, $1 \mu \mathrm{L}$ downstream primer, $0.2 \mu \mathrm{L}$ Reference Dye II, and $2.8 \mu \mathrm{L}$ cDNA diluted with $\mathrm{ddH}_{2} \mathrm{O}$ ) was used for RT-PCR. Primer sequences were designed by Primer 5.0 and shown in Table 2 . The conditions were as follows: pre-denaturation at $95^{\circ} \mathrm{C}$ for $30 \mathrm{~s}$, followed by 40 cycles of denaturation at $95{ }^{\circ} \mathrm{C}$ for $5 \mathrm{~s}$ and annealing at $60{ }^{\circ} \mathrm{C}$ for $34 \mathrm{~s}$. The expression of $\beta$-actin was shown to be consistent, and was amplified in parallel with the target genes as an inner control. The optimal annealing temperature of each primer and the range of PCR cycles was determined before the formal determination. The correlation coefficients of all the standard curves were $>0.99$, and the amplification efficiency values were between $90 \%$ and $110 \%$. At the end of target gene amplification, researchers performed a melting curve analysis to identify amplification specificity. The mRNA expression of target genes normalized with the house keeping gene $\beta$-actin was calculated with the $2^{-\Delta \Delta C t}$ method.

Table 2. Oligonucleotide primers used for a relative-quantitative real-time PCR analysis.

\begin{tabular}{|c|c|c|}
\hline Genes & Gene Bank No. & Sequences $\left(5^{\prime}-3^{\prime}\right)$ \\
\hline$\beta$-actin & AY550069.1 & $\begin{array}{l}\text { Forward: CCAGCACGATGAAGATCAAGA } \\
\text { Reverse: AATGCAACTAACAGTCCGCCTA }\end{array}$ \\
\hline Slc7a9 & NM_001110171.1 & $\begin{array}{l}\text { Forward: GAACCCAAGACCACAAATC } \\
\text { Reverse: ACCCAGTGTCGCAAGAAT }\end{array}$ \\
\hline Pept1 & AY180903.1 & $\begin{array}{l}\text { Forward: GATGAAATGTGAGCGTATGGG } \\
\text { Reverse: AAAGAGGGAGGATCTGGAAAA }\end{array}$ \\
\hline Sglt1 & NM_001164021.1 & $\begin{array}{l}\text { Forward: CСАСТТТСССТАТААААССТСАС } \\
\text { Reverse: СТССАТСАААСТТССАТССТСАG }\end{array}$ \\
\hline Glut2 & NM_001097417.1 & $\begin{array}{c}\text { Forward:CCTGCTTGGTCTATCTGCTGTG } \\
\text { Reverse:TTGATGCTTCTTCCCTTTCTTT }\end{array}$ \\
\hline$L C T$ & XM_003359430.4 & $\begin{array}{l}\text { Forward: TGTGCAGCGGTTTAAGGAGTAT } \\
\text { Reverse: CCACAACAAAGGGCTCATTCAG }\end{array}$ \\
\hline SUC & XM_013990124.1 & $\begin{array}{l}\text { Forward: TTATCCGACCCCTTTTGCATGA } \\
\text { Reverse: CGAGCATTAGGGACATAGCCTT }\end{array}$ \\
\hline$M G A M$ & XM_005657730.2 & $\begin{array}{l}\text { Forward: AGGCATCCAATTCTTCTGGAGT } \\
\text { Reverse: GGCCCCAAATGAGTCATACTGA }\end{array}$ \\
\hline DNMT1 & DQ060156.1 & $\begin{array}{l}\text { Forward: TTTCGTCTCCTTCAAGCGCT } \\
\text { Reverse: CCATACTGACCAGCCTGCAA }\end{array}$ \\
\hline DNMT3a & DQ785811.1 & $\begin{array}{l}\text { Forward: AGTGCGTGGATCTCTTGGTG } \\
\text { Reverse: TCCTGGTCGTGGTTATTGGC }\end{array}$ \\
\hline DNMT3b & NM_001162404.1 & $\begin{array}{c}\text { Forward: TGAAGAGTCCATCGCTGTTG } \\
\text { Reverse: CAATCACCAGGTCAAAGGG }\end{array}$ \\
\hline MS & AF276463 & $\begin{array}{l}\text { Forward: AGCTTTGTTCGCAGTCCAGA } \\
\text { Reverse: AAGGTCTCATTTCGGCTGCA }\end{array}$ \\
\hline MTHFR & AF239166 & $\begin{array}{l}\text { Forward: CAGTGGGAAGCAGAGGAAGG } \\
\text { Reverse: GCCACACAGACGTCGAAGTA }\end{array}$ \\
\hline BHMT & NM_001200042.1 & $\begin{array}{l}\text { Forward: GAGGCTGTGTGGGCAGTTGAAG } \\
\text { Reverse: ACAATGGATGCTCCTGCCTTTACC }\end{array}$ \\
\hline
\end{tabular}

Slc7a9, amino acid transporter light chain, family 7, member 9; Pept1, peptide transporter 1; Sglt1, sodium/glucose cotransporter 1; Glut2, glucose transporter 2; LCT, lactase; SUC, sucrase-isomaltase (alpha-glucosidase); MGAM, maltase-glucoamylase; DNMT, DNA methyl transferase; $M S$, methionine synthase; MTHFR, methylenetetrahydrofolate reductase; $B H M T$, betainehomocysteine methyltransferase.

\subsection{MassARRAY-Quantitative DNA Methylation Analysis}

The results of nutrition transporters gene expression measurement showed that Pept1 gene expression was significantly affected by the BPA and MET supplementation, and in view of its 
importance for oligopeptides transportation, this study determined the methylation status of the Pept1 promoter regions. The Cytosine-phosphoric acid-Guanine (CpG)-rich sequences for the Pept1 promoter regions were identified using the USCS genome browser, from $2000 \mathrm{bp}$ upstream of the transcriptional start point. Four different EpiTYPER assays (sense strand 2, 10, 14 and 20) were designed (EpiDesigner), which covered 8, 8, 8 and 13 CpG sites respectively (successful data were generated for 6, 6, 7 and 6 CpG sites). The primer sequences and the locations relative to the translational start codon for the assays are presented in Table 3. Quantitative methylation analysis of the porcine Pept1 promoter was performed using Sequenom's MassARRAY EpiTYPER protocol (Sequenom, San Diego, CA, USA). Genomic DNA was extracted from the newborn piglets' intestine using a Wizard Genomic DNA Purification Kit (Promega Corporation, Madison, WI, USA), and then bisulfite-treated with the EZ DNA Methylation Kit (Zymo Research, Orange, CA, USA). Specific PCR was carried out with the bisulfate-modified DNA. The conditions were as follows: $94{ }^{\circ} \mathrm{C}$ for four minutes followed by 45 cycles of $94{ }^{\circ} \mathrm{C}$ for $20 \mathrm{~s}, 52-62{ }^{\circ} \mathrm{C}$ for $30 \mathrm{~s}$ and $72{ }^{\circ} \mathrm{C}$ for three minutes. The PCR products were detected on agarose gel before the further analysis. In vitro transcription and RNase cleavage reaction were conducted using the Mass Cleave (hMC) kit. Transcription cleavage products were dispensed onto a 384 element SpectroCHIP bioassay, and the mass spectra were acquired through a MassARRAY mass spectrometer (Sequenom). The spectra were analyzed and the methylation rations were obtained by the EpiTYPER software v.1.0 (Sequenom). Each step of the above operation was performed in strict accordance with the corresponding manufacturer's instructions.

Table 3. The primer sequences and the locations relative to the translational start codon for the assays in MassARRAY-quantitative DNA methylation analysis.

\begin{tabular}{|c|c|c|}
\hline Assays & Sequences $\left(5^{\prime}-3^{\prime}\right)$ & Location \\
\hline Pept1-2 & $\begin{array}{l}\text { Forward: GTGGGGTTAGATTTTTTTAAAATGG } \\
\text { Reverse: AAAAAAAACCACATCCACAAATAAA }\end{array}$ & -968 to -1481 \\
\hline Pept1-10 & $\begin{array}{l}\text { Forward: GTTTATTTGGGTGGAGATTGTTTAG } \\
\text { Reverse: ACCCTTAACCCAATAAATAAAACCA }\end{array}$ & -1450 to -1089 \\
\hline Pept1-14 & $\begin{array}{l}\text { Forward: AGTTTATATTTGGTGTGGTTGTGGT } \\
\text { Reverse: CCCACCTCCCTATATTAACAAAAAA }\end{array}$ & -1050 to -599 \\
\hline Pept1-20 & $\begin{array}{l}\text { Forward: GTTGGGTGTTAGGTATTTTTAAGGG } \\
\text { Reverse: AACAAAACCAACTATAAAACTCCCA }\end{array}$ & -390 to +75 \\
\hline
\end{tabular}

Pept1, peptide transporter 1.

\subsection{Statistical Analysis}

Raw data were preliminarily processed with MS Excel, with further data analysis performed by two-way ANOVA using SPSS Statistics 20 (IBM ${ }^{\circledR}$ SPSS ${ }^{\circledR}$ Statistics, New York, NY, USA). Data were tested for normality and homogeneity of variances (Shapiro-Wilk and Levene tests, respectively) and when necessary data were normalized (arcsine, square root or logarithm normalized) to achieve ANOVA assumptions. Additionally, Duncan's multiple range tests were conducted to determine difference among the treatments. All data were expressed as mean and standard error. $p<0.05$ was considered statistically significant.

\section{Results}

\subsection{Intestinal Index}

Maternal BPA exposure during gestation had no significant effect on the intestinal index. However, MET supplementation significantly decreased the ratio of SI length to body weight but increased the ratio of SI weight to length both in newborn and weaning piglets $(p<0.05)$ (Table 4$)$. 
Table 4. Effect of maternal methyl donor or bisphenol A supplementation during gestation on intestinal index in newborn and weaning pigs.

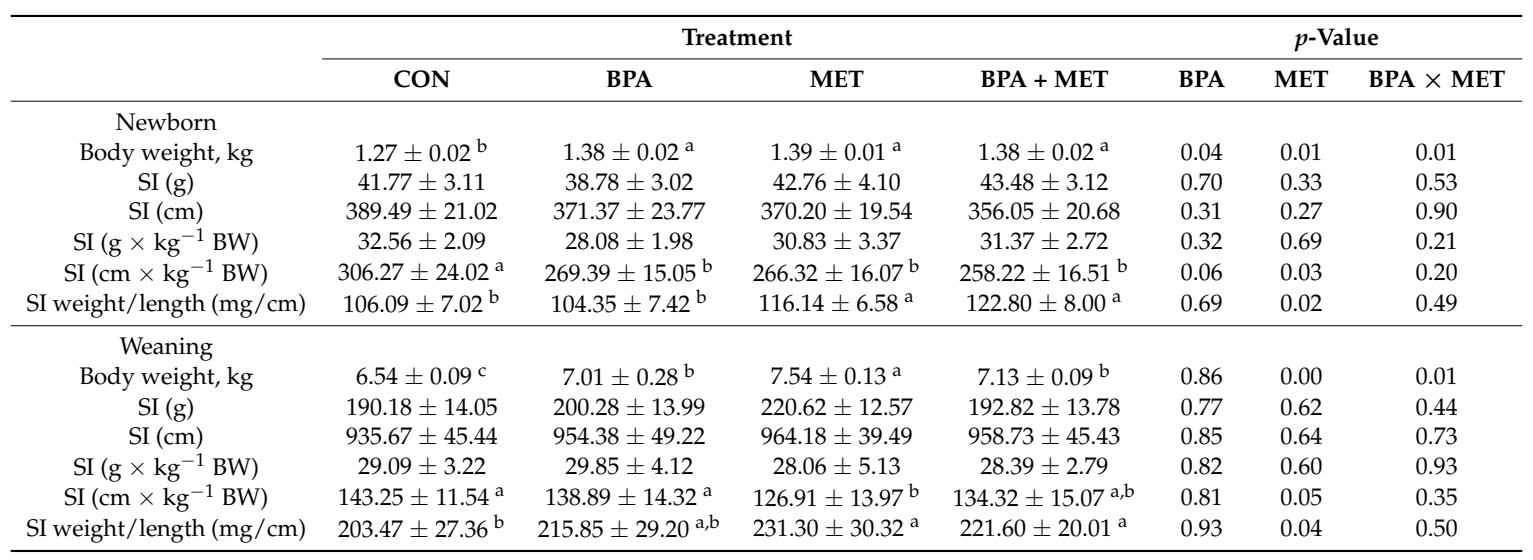

CON, control; BPA, bisphenol A; MET, methyl donor; BPA + MET, both bisphenol A and methyl donor supplementation in control diet; SI, Small intestine. Different superscript letters within a row indicate significant difference $(p<0.05)$. At birth, 12 independent samples per treatment group (total 48); at weaning, six independent samples per treatment group (total 24).

\subsection{Intestinal Morphology}

Maternal BPA supplementation during gestation significantly reduced the ratio of jejunum villus height to crypt depth in newborn and weaning offspring $(p<0.05)$. Maternal MET supplementation significantly increased the jejunum villus height of newborn piglets, and the ratio of jejunum and ileum villus height to crypt depth both in newborn and weaning piglets $(p<0.05)$. Additionally, the ratio of jejunum villus height to crypt depth in newborn offspring and the ratio of ileum villus height to crypt depth in weaning offspring were significantly influenced by BPA $\times$ MET interaction $(p<0.05)$ (Table 5$)$.

Table 5. Effect of maternal methyl donor or bisphenol A supplementation during gestation on intestinal morphology in newborn and weaning pigs.

\begin{tabular}{|c|c|c|c|c|c|c|c|}
\hline & \multicolumn{4}{|c|}{ Treatment } & \multicolumn{3}{|c|}{$p$-Value } \\
\hline & $\mathrm{CON}$ & BPA & MET & BPA + MET & BPA & MET & BPA $\times$ MET \\
\hline \multicolumn{8}{|l|}{ Newborn } \\
\hline \multicolumn{8}{|l|}{ Duodenum } \\
\hline Villus height $(\mu \mathrm{m})$ & $479.86 \pm 33.57$ & $442.69 \pm 37.11$ & $522.68 \pm 39.52$ & $512.70 \pm 34.79$ & 0.70 & 0.37 & 0.83 \\
\hline Crypt depth $(\mu \mathrm{m})$ & $125.57 \pm 11.50$ & $126.45 \pm 13.47$ & $127.25 \pm 12.98$ & $131.08 \pm 14.01$ & 0.78 & 0.71 & 0.86 \\
\hline Villus/crypt ratio & $3.87 \pm 0.43$ & $3.50 \pm 0.32$ & $3.94 \pm 0.27$ & $4.12 \pm 0.38$ & 0.85 & 0.49 & 0.59 \\
\hline \multicolumn{8}{|l|}{ Jejunum } \\
\hline Villus height $(\mu \mathrm{m})$ & $639.99 \pm 59.30^{b}$ & $649.53 \pm 61.37^{b}$ & $740.11 \pm 60.54^{a}$ & $717.39 \pm 55.83^{a}$ & 0.75 & 0.05 & 0.82 \\
\hline Crypt depth $(\mu \mathrm{m})$ & $104.73 \pm 6.91$ & $114.33 \pm 7.12$ & $102.18 \pm 5.90$ & $99.11 \pm 7.01$ & 0.61 & 0.17 & 0.33 \\
\hline Villus/crypt ratio & $5.94 \pm 0.62^{b}$ & $4.19 \pm 0.57^{c}$ & $7.99 \pm 0.52^{\mathrm{a}}$ & $8.69 \pm 0.71^{a}$ & 0.04 & 0.02 & 0.04 \\
\hline \multicolumn{8}{|l|}{ Ileum } \\
\hline Villus height $(\mu \mathrm{m})$ & $579.19 \pm 50.11$ & $530.19 \pm 53.25$ & $620.89 \pm 51.33$ & $653.98 \pm 52.17$ & 0.92 & 0.31 & 0.61 \\
\hline Crypt depth $(\mu \mathrm{m})$ & $111.18 \pm 13.29$ & $122.27 \pm 10.12$ & $95.33 \pm 9.02$ & $127.51 \pm 9.74$ & 0.07 & 0.64 & 0.36 \\
\hline Villus/crypt ratio & $5.58 \pm 0.54^{\mathrm{b}}$ & $5.19 \pm 0.62^{b}$ & $6.45 \pm 0.56^{\mathrm{a}}$ & $5.86 \pm 0.48^{a, b}$ & 0.86 & 0.03 & 0.75 \\
\hline \multicolumn{8}{|l|}{ Weaning } \\
\hline \multicolumn{8}{|l|}{ Duodenum } \\
\hline Villus height $(\mu \mathrm{m})$ & $287.91 \pm 22.89$ & $277.98 \pm 25.37$ & $324.57 \pm 21.09$ & $308.72 \pm 19.88$ & 0.73 & 0.36 & 0.94 \\
\hline Crypt depth $(\mu \mathrm{m})$ & $178.45 \pm 10.30$ & $171.55 \pm 9.02$ & $174.37 \pm 11.06$ & $183.46 \pm 13.00$ & 0.95 & 0.82 & 0.64 \\
\hline Villus/crypt ratio & $1.74 \pm 0.12$ & $1.62 \pm 0.22$ & $1.96 \pm 0.15$ & $1.89 \pm 0.12$ & 0.61 & 0.20 & 0.90 \\
\hline \multicolumn{8}{|l|}{ Jejunum } \\
\hline Villus height $(\mu \mathrm{m})$ & $264.71 \pm 19.03$ & $243.04 \pm 21.24$ & $331.47 \pm 24.01$ & $274.58 \pm 20.59$ & 0.27 & 0.17 & 0.61 \\
\hline Crypt depth $(\mu \mathrm{m})$ & $132.93 \pm 9.77$ & $142.21 \pm 10.02$ & $133.97 \pm 8.29$ & $120.26 \pm 9.15$ & 0.84 & 0.34 & 0.30 \\
\hline Villus/crypt ratio & $2.04 \pm 0.15^{b}$ & $1.51 \pm 0.12^{c}$ & $2.54 \pm 0.12^{\mathrm{a}}$ & $2.60 \pm 0.13^{\mathrm{a}}$ & 0.02 & 0.03 & 0.48 \\
\hline \multicolumn{8}{|l|}{ Ileum } \\
\hline Villus height $(\mu \mathrm{m})$ & $206.80 \pm 39.56$ & $233.29 \pm 33.47$ & $291.58 \pm 36.90$ & $314.50 \pm 35.36$ & 0.67 & 0.20 & 0.99 \\
\hline Crypt depth $(\mu \mathrm{m})$ & $113.45 \pm 7.89$ & $129.57 \pm 8.03$ & $122.36 \pm 9.76$ & $106.86 \pm 12.04$ & 0.98 & 0.60 & 0.24 \\
\hline Villus/crypt ratio & $1.84 \pm 0.08^{b}$ & $1.83 \pm 0.08^{b}$ & $2.58 \pm 0.09^{\mathrm{a}}$ & $1.85 \pm 0.010^{b}$ & 0.64 & 0.02 & 0.02 \\
\hline
\end{tabular}

CON, control; BPA, bisphenol A; MET, methyl donor; BPA + MET, both bisphenol A and methyl donor supplementation in control diet. Different superscript letters within a row indicate significant difference $(p<0.05)$. At birth, 12 independent samples per treatment group (total 48); at weaning, six independent samples per treatment group (total 24). 


\subsection{Disaccharidase Activity}

Maternal BPA supplementation during gestation significantly decreased the activity of jejunum sucrase in offspring both at birth and weaning $(p<0.05)$. Maternal MET supplementation significantly improved the activity of jejunum lactase in both newborn and weaning pigs, and the activity of duodenum and jejunum sucrase in weaning piglets $(p<0.05)$. The activity of jejunum lactase in newborn and weaning pigs was significantly affected by BPA $\times$ MET interaction $(p<0.05)$ (Table 6$)$.

Table 6. Effect of maternal methyl donor or bisphenol A supplementation during gestation on intestinal enzyme activity in newborn and weaning pigs.

\begin{tabular}{|c|c|c|c|c|c|c|c|}
\hline & \multicolumn{4}{|c|}{ Treatment } & \multicolumn{3}{|c|}{$p$-Value } \\
\hline & $\mathrm{CON}$ & BPA & MET & BPA + MET & BPA & MET & BPA $\times$ MET \\
\hline \multicolumn{8}{|l|}{ Newborn Duodenum } \\
\hline Lactase (U/mgprotein) & $189.27 \pm 31.20$ & $185.04 \pm 34.18$ & $191.52 \pm 36.03$ & $187.91 \pm 40.85$ & 0.91 & 0.94 & 0.99 \\
\hline Maltase (U/mgprotein) & $6.99 \pm 1.18$ & $6.76 \pm 1.04$ & $7.70 \pm 0.99$ & $7.42 \pm 1.10$ & 0.82 & 0.53 & 0.98 \\
\hline Sucrase (U/mgprotein) & $1.75 \pm 0.63$ & $1.89 \pm 0.77$ & $2.43 \pm 0.73$ & $2.05 \pm 0.98$ & 0.88 & 0.60 & 0.75 \\
\hline \multicolumn{8}{|l|}{ Jejunum } \\
\hline Lactase (U/mgprotein) & $167.50 \pm 28.77^{b}$ & $166.28 \pm 27.43^{b}$ & $193.07 \pm 30.33^{\mathrm{a}}$ & $184.18 \pm 30.33^{a}$ & 0.86 & 0.04 & 0.05 \\
\hline Maltase (U/mgprotein)) & $9.02 \pm 1.10$ & $8.91 \pm 1.10$ & $7.46 \pm 1.16$ & $8.34 \pm 1.05$ & 0.72 & 0.35 & 0.65 \\
\hline Sucrase (U/mgprotein) & $1.73 \pm 0.24^{\mathrm{a}}$ & $1.00 \pm 0.27^{b}$ & $1.80 \pm 0.23^{\mathrm{a}}$ & $1.10 \pm 0.23^{\mathrm{a}, \mathrm{b}}$ & $<0.01$ & 0.74 & 0.95 \\
\hline \multicolumn{8}{|l|}{ Ileum } \\
\hline Lactase (U/mgprotein) & $29.23 \pm 5.03$ & $24.33 \pm 4.77$ & $30.48 \pm 4.55$ & $31.27 \pm 6.16$ & 0.69 & 0.43 & 0.59 \\
\hline Maltase (U/mgprotein)) & $8.82 \pm 1.10$ & $5.86 \pm 1.04$ & $7.83 \pm 0.95$ & $8.62 \pm 1.17$ & 0.08 & 0.28 & 0.75 \\
\hline Sucrase (U/mgprotein) & $1.22 \pm 0.19$ & $0.92 \pm 0.18$ & $0.91 \pm 0.21$ & $0.97 \pm 0.22$ & 0.58 & 0.52 & 0.38 \\
\hline \multicolumn{8}{|l|}{ Weaning Duodenum } \\
\hline Lactase (U/mgprotein)) & $24.55 \pm 10.67$ & $32.45 \pm 11.93$ & $46.93 \pm 10.67$ & $35.13 \pm 11.93$ & 0.87 & 0.29 & 0.40 \\
\hline Maltase (U/mgprotein) & $49.72 \pm 9.44$ & $48.05 \pm 9.34$ & $50.66 \pm 12.19$ & $45.75 \pm 10.56$ & 0.76 & 0.95 & 0.88 \\
\hline Sucrase (U/mgprotein) & $7.71 \pm 2.18^{b}$ & $8.61 \pm 2.44^{b}$ & $15.84 \pm 2.41^{\mathrm{a}}$ & $12.35 \pm 2.82^{a}$ & 0.75 & 0.02 & 0.51 \\
\hline \multicolumn{8}{|l|}{ Jejunum } \\
\hline Lactase (U/mgprotein) & $48.22 \pm 8.98^{b}$ & $47.18 \pm 11.59^{b}$ & $72.03 \pm 8.20^{\mathrm{a}}$ & $67.03 \pm 11.59^{a, b}$ & 0.85 & 0.05 & 0.05 \\
\hline Maltase (U/mgprotein) & $121.33 \pm 23.82$ & $102.37 \pm 29.17$ & $131.34 \pm 23.32$ & $143.15 \pm 29.17$ & 0.55 & 0.84 & 0.20 \\
\hline Sucrase (U/mgprotein) & $51.61 \pm 13.50^{b}$ & $43.53 \pm 9.53^{b}$ & $81.90 \pm 13.50^{\mathrm{a}}$ & $69.98 \pm 13.50^{a, b}$ & 0.07 & 0.01 & 0.22 \\
\hline \multicolumn{8}{|l|}{ Ileum } \\
\hline Lactase (U/mgprotein) & $5.99 \pm 2.51$ & $5.13 \pm 2.49$ & $6.64 \pm 2.81$ & $6.35 \pm 2.61$ & 0.56 & 0.50 & 0.97 \\
\hline Maltase (U/mgprotein) & $80.81 \pm 18.40$ & $50.25 \pm 18.40$ & $83.58 \pm 18.40$ & $73.34 \pm 16.79$ & 0.27 & 0.48 & 0.58 \\
\hline Sucrase (U/mgprotein) & $35.42 \pm 11.98$ & $29.20 \pm 10.32$ & $32.33 \pm 11.42$ & $39.14 \pm 10.94$ & 0.98 & 0.77 & 0.59 \\
\hline
\end{tabular}

CON, control; BPA, bisphenol A; MET, methyl donor; BPA + MET, both bisphenol A and methyl donor supplementation in control diet. Different superscript letters within a row indicate significant difference $(p<0.05)$. At birth, 12 independent samples per treatment group (total 48); at weaning, six independent samples per treatment group (total 24).

\subsection{Nutrient Transporter Gene Expression}

Maternal BPA supplementation during gestation significantly down-regulated the mRNA relative expression of jejunum Pept1 and SUC in newborn piglets $(p<0.05)$. Maternal MET supplementation significantly up-regulated the mRNA relative expression of jejunum Pept1, Sglt1 and LCT in newborn offspring and weaning offspring. SUC was only affected at birth $(p<0.05)$. Compared with the BPA group, the mRNA relative expression of jejunum Pept1 was significantly increased in the BPA + MET group at birth and weaning $(p<0.05)$ (Table 7$)$.

\section{5. $C p$ G Methylation}

In jejunum tissue of newborn pigs, maternal BPA exposure during gestation significantly reduced the methylation rate of the CpG site $-18,-66,-93,-215,-688,-721,-1352,-1544,-1705$ and -1771 on the Pept1 promoter region $(p<0.05)$ (Table 8$)$. Whereas the methylation rates of these CpG sites, except the -1771 site, were significantly increased by maternal MET supplementation $(p<0.05)$, the methylation rates of $\mathrm{CPG}$ sites -93 and -721 were significantly influenced by BPA $\times$ MET interaction $(p<0.05)$. Compared with the BPA group, the average methylation of $\mathrm{CpG}$ sites at jejunum Pept1 promoter was significantly increased in the BPA + MET group (Figure 1). 
Table 7. Effect of maternal methyl donor or bisphenol A supplementation during gestation on mRNA relative expression of nutrient transporters and disaccharidases in jejunum of newborn and weaning piglets.

\begin{tabular}{|c|c|c|c|c|c|c|c|}
\hline & \multicolumn{4}{|c|}{ Treatment } & \multicolumn{3}{|c|}{$p$-Value } \\
\hline & $\mathrm{CON}$ & BPA & MET & BPA + MET & BPA & MET & BPA $\times$ MET \\
\hline \multicolumn{8}{|l|}{ Newborn } \\
\hline Slc7a9 & $1.00 \pm 0.32$ & $0.86 \pm 0.18$ & $1.15 \pm 0.18$ & $0.97 \pm 0.21$ & 0.56 & 0.64 & 0.94 \\
\hline Pept1 & $1.00 \pm 0.26^{b}$ & $0.54 \pm 0.10^{c}$ & $2.35 \pm 0.22^{\mathrm{a}}$ & $1.07 \pm 0.21^{b}$ & $<0.01$ & $<0.01$ & 0.11 \\
\hline Sglt1 & $1.00 \pm 0.10^{\mathrm{c}}$ & $1.16 \pm 0.14^{b, c}$ & $2.37 \pm 0.21^{\mathrm{a}}$ & $1.59 \pm 0.18^{b}$ & 0.10 & $<0.01$ & 0.01 \\
\hline Glut2 & $1.00 \pm 0.23$ & $0.73 \pm 0.17$ & $1.40 \pm 0.27$ & $0.83 \pm 0.18$ & 0.09 & 0.31 & 0.54 \\
\hline$L C T$ & $1.00 \pm 0.14^{\mathrm{c}}$ & $1.24 \pm 0.16^{b, c}$ & $2.90 \pm 0.25^{\mathrm{a}}$ & $1.89 \pm 0.10^{b}$ & 0.67 & $<0.01$ & 0.05 \\
\hline SUC & $1.00 \pm 0.13^{b}$ & $0.53 \pm 0.08^{c}$ & $1.76 \pm 0.12^{\mathrm{a}}$ & $1.35 \pm 0.06^{\mathrm{a}, \mathrm{b}}$ & 0.04 & 0.11 & 0.20 \\
\hline$M G A M$ & $1.00 \pm 0.09$ & $1.42 \pm 0.13$ & $1.62 \pm 0.17$ & $1.22 \pm 0.20$ & 0.34 & 0.29 & 0.57 \\
\hline \multicolumn{8}{|l|}{ Weaning } \\
\hline Slc7a9 & $1.00 \pm 0.11$ & $0.97 \pm 0.26$ & $0.99 \pm 0.17$ & $1.02 \pm 0.19$ & 1.00 & 0.92 & 0.87 \\
\hline Pept1 & $1.00 \pm 0.35^{b, c}$ & $0.40 \pm 0.10^{c}$ & $1.84 \pm 0.22^{\mathrm{a}}$ & $1.37 \pm 0.35^{\mathrm{a}, \mathrm{b}}$ & 0.05 & $<0.01$ & 0.81 \\
\hline Sglt1 & $1.00 \pm 0.18^{b}$ & $0.88 \pm 0.29^{b}$ & $2.14 \pm 0.40^{\mathrm{a}}$ & $1.25 \pm 0.31^{\mathrm{a}, \mathrm{b}}$ & 0.13 & 0.03 & 0.24 \\
\hline Glut2 & $1.00 \pm 0.23$ & $1.03 \pm 0.16$ & $1.42 \pm 0.32$ & $1.30 \pm 0.34$ & 0.87 & 0.24 & 0.79 \\
\hline$L C T$ & $1.00 \pm 0.13^{b}$ & $0.85 \pm 0.15^{b}$ & $1.73 \pm 0.27^{\mathrm{a}}$ & $0.93 \pm 0.09^{b}$ & 0.71 & 0.04 & 0.91 \\
\hline SUC & $1.00 \pm 0.12$ & $1.02 \pm 0.09$ & $1.15 \pm 0.13$ & $1.41 \pm 0.07$ & 0.95 & 0.89 & 0.09 \\
\hline$M G A M$ & $1.00 \pm 0.09$ & $1.18 \pm 0.12$ & $1.28 \pm 0.16$ & $1.20 \pm 0.21$ & 0.77 & 0.65 & 0.81 \\
\hline
\end{tabular}

CON, control; BPA, bisphenol A; MET, methyl donor; BPA + MET, both bisphenol A and methyl donor supplementation in control diet; Clc7a9, amino acid transporter light chain, family 7, member 9; Pept1, peptide transporter 1; Sglt1, sodium/glucose co-transporter 1; Glut2, glucose transporter 2; LCT, lactase; SUC, sucrase-isomaltase (alpha-glucosidase); MGAM, maltase-glucoamylase. Data are normalized against $\beta$-actin, with results expressed relative to the control sample using the ${ }^{\Delta \Delta} \mathrm{Ct}$ method (where $\mathrm{Ct}$ is the cycle threshold) with efficiency correction. Values are expressed as mean \pm standard error; different superscript letters within a row indicate significant difference $(p<0.05)$. At birth, 12 independent samples per treatment group (total 48$)$; at weaning, six independent samples per treatment group (total 24).

Table 8. Effect of maternal methyl donor or bisphenol A supplementation during gestation on the jejunum Pept1 gene DNA methylation level in newborn pigs.

\begin{tabular}{|c|c|c|c|c|c|c|c|}
\hline \multirow{2}{*}{ CpG Site } & \multicolumn{4}{|c|}{ Treatment } & \multicolumn{3}{|c|}{$p$-Value } \\
\hline & $\mathrm{CON}$ & BPA & MET & BPA + MET & BPA & MET & BPA $\times$ MET \\
\hline-18 & $0.54 \pm 0.03^{b}$ & $0.46 \pm 0.05^{b}$ & $0.70 \pm 0.05^{\mathrm{a}}$ & $0.53 \pm 0.05^{b}$ & 0.02 & 0.02 & 0.33 \\
\hline-66 & $0.56 \pm 0.03^{b}$ & $0.19 \pm 0.04^{c}$ & $0.93 \pm 0.04^{\mathrm{a}}$ & $0.46 \pm 0.04^{b}$ & $<0.01$ & $<0.01$ & 0.23 \\
\hline-93 & $0.87 \pm 0.04^{\mathrm{a}, \mathrm{b}}$ & $0.35 \pm 0.04^{c}$ & $0.94 \pm 0.01^{\mathrm{a}}$ & $0.78 \pm 0.06^{b}$ & $<0.01$ & $<0.01$ & $<0.01$ \\
\hline-149 & $0.76 \pm 0.06$ & $0.72 \pm 0.02$ & $0.77 \pm 0.02$ & $0.76 \pm 0.02$ & 0.49 & 0.54 & 0.68 \\
\hline-215 & $0.59 \pm 0.07^{b}$ & $0.39 \pm 0.05^{c}$ & $0.89 \pm 0.04^{\mathrm{a}}$ & $0.52 \pm 0.03^{b, c}$ & $<0.01$ & $<0.01$ & 0.12 \\
\hline-278 & $0.87 \pm 0.01$ & $0.84 \pm 0.02$ & $0.87 \pm 0.06$ & $0.84 \pm 0.02$ & 0.35 & 0.94 & 1.00 \\
\hline-655 & $0.75 \pm 0.03$ & $0.50 \pm 0.17$ & $0.74 \pm 0.03$ & $0.75 \pm 0.01$ & 0.19 & 0.18 & 0.15 \\
\hline-672 & $0.79 \pm 0.03$ & $0.61 \pm 0.21$ & $0.78 \pm 0.04$ & $0.77 \pm 0.02$ & 0.38 & 0.49 & 0.44 \\
\hline-688 & $0.36 \pm 0.07^{b}$ & $0.18 \pm 0.06^{c}$ & $0.71 \pm 0.09^{a}$ & $0.51 \pm 0.14^{b}$ & $<0.01$ & $<0.01$ & 0.88 \\
\hline-704 & $0.44 \pm 0.13$ & $0.18 \pm 0.14$ & $0.39 \pm 0.12$ & $0.38 \pm 0.13$ & 0.32 & 0.59 & 0.37 \\
\hline-721 & $0.63 \pm 0.04^{b}$ & $0.33 \pm 0.04^{c}$ & $0.94 \pm 0.03^{\mathrm{a}}$ & $0.83 \pm 0.04^{\mathrm{a}}$ & $<0.01$ & $<0.01$ & 0.03 \\
\hline-774 & $0.76 \pm 0.06$ & $0.50 \pm 0.17$ & $0.73 \pm 0.02$ & $0.74 \pm 0.03$ & 0.22 & 0.29 & 0.17 \\
\hline-1159 & $0.19 \pm 0.09$ & $0.22 \pm 0.13$ & $0.19 \pm 0.11$ & $0.21 \pm 0.14$ & 0.83 & 0.95 & 0.99 \\
\hline-1169 & $0.93 \pm 0.01$ & $0.94 \pm 0.01$ & $0.93 \pm 0.01$ & $0.91 \pm 0.01$ & 0.85 & 0.26 & 0.34 \\
\hline-1203 & $0.13 \pm 0.07$ & $0.15 \pm 0.08$ & $0.15 \pm 0.08$ & $0.16 \pm 0.09$ & 0.87 & 0.82 & 0.99 \\
\hline-1252 & $0.15 \pm 0.06$ & $0.16 \pm 0.01$ & $0.20 \pm 0.02$ & $0.16 \pm 0.03$ & 0.72 & 0.54 & 0.54 \\
\hline-1352 & $0.77 \pm 0.05^{\mathrm{a}}$ & $0.38 \pm 0.03^{b}$ & $0.87 \pm 0.04^{\mathrm{a}}$ & $0.43 \pm 0.03^{b}$ & $<0.01$ & 0.06 & 0.64 \\
\hline-1417 & $0.10 \pm 0.06$ & $0.09 \pm 0.05$ & $0.11 \pm 0.06$ & $0.07 \pm 0.07$ & 0.73 & 0.86 & 0.79 \\
\hline-1544 & $0.47 \pm 0.05^{b}$ & $0.31 \pm 0.05^{c}$ & $0.64 \pm 0.05^{\mathrm{a}}$ & $041 \pm 0.04^{\mathrm{a}, \mathrm{b}}$ & $<0.01$ & 0.01 & 0.45 \\
\hline-1694 & $0.60 \pm 0.03$ & $0.61 \pm 0.02$ & $0.61 \pm 0.02$ & $0.59 \pm 0.02$ & 0.88 & 0.80 & 0.52 \\
\hline-1705 & $0.28 \pm 0.06^{c}$ & $0.20 \pm 0.05^{c}$ & $0.67 \pm 0.04^{\mathrm{a}}$ & $0.47 \pm 0.07^{b}$ & 0.03 & $<0.01$ & 0.35 \\
\hline-1718 & $0.05 \pm 0.01$ & $0.06 \pm 0.02$ & $0.07 \pm 0.02$ & $0.05 \pm 0.02$ & 0.82 & 0.94 & 0.34 \\
\hline-1771 & $0.34 \pm 0.03^{\mathrm{a}}$ & $0.23 \pm 0.03^{b}$ & $0.33 \pm 0.05^{\mathrm{a}, \mathrm{b}}$ & $0.26 \pm 0.03^{a, b}$ & 0.02 & 0.72 & 0.48 \\
\hline-1795 & $0.92 \pm 0.01$ & $0.92 \pm 0.02$ & $0.91 \pm 0.02$ & $0.93 \pm 0.03$ & 0.72 & 0.90 & 0.72 \\
\hline-1908 & $0.33 \pm 0.04$ & $0.34 \pm 0.01$ & $0.32 \pm 0.02$ & $0.31 \pm 0.01$ & 0.76 & 0.36 & 0.61 \\
\hline
\end{tabular}

CON, control; BPA, bisphenol A; MET, methyl donor; BPA + MET, both bisphenol A and methyl donor supplementation in control diet. Different superscript letters within a row indicate significant difference $(p<0.05)$. Four independent samples per treatment group (total 16). 


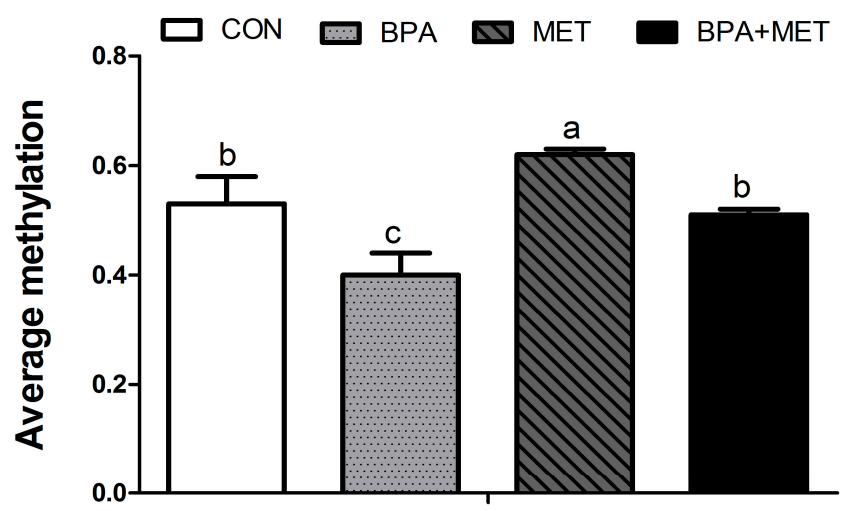

Figure 1. Effect of maternal methyl donor or bisphenol A supplementation during gestation on the jejunum Pept1 gene DNA average methylation level in newborn pigs. CON, control; BPA, bisphenol A; MET, methyl donor; BPA + MET, both bisphenol A and methyl donor supplementation in control diet. Values are expressed as mean \pm standard error; different superscript letters within a row indicate significant difference $(p<0.05)$. Four independent samples per treatment group (total 16).

\subsection{Methylation-Related Gene Expression}

Maternal BPA supplementation during gestation significantly reduced the mRNA relative expression of jejunum DNMT3a in newborn offspring $(p<0.05)$. Maternal MET supplementation significantly increased the mRNA relative expression of jejunum DNMT1, DNMT3a and MTHFR in newborn piglets $(p<0.05)$. Compared with the BPA group, the mRNA relative expression of jejunum DNMT3a was significantly increased in the BPA + MET group at birth $(p<0.05)$ (Figure 2).

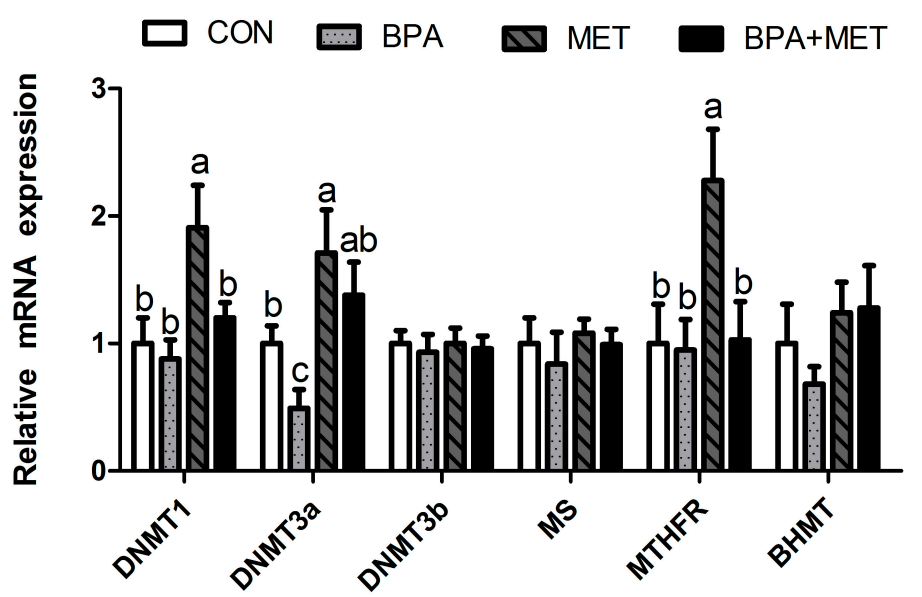

Figure 2. Effect of maternal methyl donor or bisphenol A supplementation during gestation on mRNA relative expression of key enzymes related to DNA methylation in jejunum of newborn piglets. CON, control; BPA, bisphenol A; MET, methyl donor; BPA + MET, both bisphenol A and methyl donor supplementation in control diet; DNMT, DNA methyl transferase; MS, methionine synthase; MTHFR, methylenetetrahydrofolate reductase; BHMT, betaine homocysteine methyltransferase. Data are normalized against $\beta$-actin, with results expressed relative to the control sample using the ${ }^{\Delta \Delta} \mathrm{Ct}$ method (where $C t$ is the cycle threshold) with efficiency correction. Values are expressed as mean \pm standard error; different superscript letters within a row indicate significant difference $(p<0.05)$. 12 independent samples per treatment group (total 48). 


\section{Discussion}

This was the first study to focus on the effect of maternal BPA exposure during pregnancy on intestinal digestion and absorption function in offspring. In this study, the ratio of jejunum villus height to crypt depth in newborn and weaning pigs was significantly decreased by maternal BPA exposure. The ratio of villus height to crypt depth reflects the capacity of the small intestine for nutrient digestion and absorption to a certain extent [23]. The proliferation and differentiation of intestinal epithelial cells is accompanied by their migration along the crypt-villus axis [24]. Thus, a lower ratio of villus height to crypt depth may indicate less proliferation and differentiation. It is logical to consider that maternal BPA exposure may suppress digestion and absorption function through inhibiting the proliferation and differentiation of intestinal epithelial cells in offspring. Researchers have reported that prenatal exposure to BPA affected immune function in offspring; resulting in higher IFN- $\gamma$ and IL-4, and lower $\mathrm{CD}^{+}$and CD25 ${ }^{+}$cells $[5,25,26]$, which were closely related to the proliferation of epithelial cells $[27,28]$. Most mature intestine epithelial cells have the function of synthesis and secretion of digestive enzymes [29].

In this study, the jejunum sucrose activity in offspring was significantly decreased in response to BPA exposure, which was consistent with the SUC mRNA expression. Lactose is the main source of mammalian carbohydrate during lactation, so lactase is the dominant enzyme in the intestine of suckling piglets [30]. However, with the increase of age (especially after weaning), maltase and sucrase gradually become dominant enzymes. The results showed that the jejunal lactase in neonatal and weaned piglets was not significantly affected by BPA, but sucrose was. It implied that BPA exposure during pregnancy did not significantly affect the energy intake of newborn piglets, but might have an impact with increasing age. This may be the reason that the average body weight of piglets in the BPA group was not significantly different from that in the MET group at birth, but tended to be lower at weaning. However, this mechanism requires further study.

Consistently, the development of absorption function in the intestine relied greatly on the intestinal nutrient transporter [31]. Increasing intestinal absorption is generally linked to the elevated expression of nutrient transporters [32]. In this research, the jejunum Pept1 mRNA level was observed to be significantly decreased in BPA-exposed offspring. Pept1 is located at the brush-border membrane of intestinal epithelial cells and mediates cellular uptake of these oligopeptides by using an inwardly directed $\mathrm{H}^{+}$gradient across the brush-border membrane [33]. Therefore, the transfer and absorption of oligopeptides were closely related to the Pept1 gene expression [34].

Recently, a growing number of studies showed changes in gene expression due to BPA, especially the long-term effects but at low does, possibly involving epigenetic pathways [35]. In this study, a significant decrease of the average methylation rate on the jejunum Pept1 promoter region in newborn BPA-pigs was obtained. Researchers found that the CpG sites -1771 and -721 , where the methylation rate were decreased, were located in the transcription factor cAMP-response element binding protein (CREB) binding sites, and CpG sites $-1544,-1352$ and-93 were located in the transcription factor stimulatory protein 1 (SP1) binding sites. Studies have demonstrated the importance of the transcription factors CREB and SP1 in up-regulation of Pept1 expression [36,37]. Traditionally, many researchers tend to deem that CpG islands (CGIs) are mostly not methylated when located at the upstream promoter of transcription start sites. Once methylated by external environmental factors, methylated CGIs can result in stable repression of the linked gene, likely by preventing them from binding to transcription factors [38]. However, this study seemed inconsistent with this hypothesis. The most reasonable explanation is that there are just CpG sites, but no CGIs in the promoter of Pept1.The functional relevance of reduced methylation at CG-poor regulatory regions is still unclear. Although the related mechanisms remain unclear, this study indicated that Pept1 gene expression decline via hypomethylation modifications was a mechanism by which the maternal BPA was not beneficial for oligopeptides transfer and absorption in offspring. It is known that DNMT3a is one of the DNA methyltransferases, catalyzing the formation of de novo methylation [39]. In this study, mRNA-relative expression of jejunum DNMT3a in BPA-exposed newborn pigs was significantly 
decreased, which indicated that BPA-induced hypomethylation was likely through decreased DNA methyltransferases. Research has shown that the effects of BPA were manifested in disrupted fetal metabolic programming through hypomethylation modifications via decreased DNMT, even though the concrete mechanisms remain unclear [40].

The intestinal morphology results suggested that MET could induce the increase of the intestinal epithelial cell proliferation as demonstrated by the increased ratio of villus height to crypt depth in MET offspring pigs. A similar study reported that the maternal MET (vitamin B12, folate and choline) deficiency during gestation and lactation in rats induced higher intestinal crypt apoptosis and lower villi epithelial cell differentiation in offspring [41]. Consistent with the intestinal morphology results, we found that jejunum mucosal lactase activity and the expression of the lactase gene were significantly increased in MET offspring, which meant a better digestion ability for lactose. Lactose is the major carbohydrate in milk of most placental mammals, and lactase plays a dominant role in digestion of disaccharide before weaning [30].

In this study, MET increased the Pept1 and Sglt1 genes expression in newborn pigs' jejunum, which were positively correlated with transportation and absorption for oligopeptides and glucose. Studies have shown that the changes of gene expression resulted from MET were closely related to DNA methylation [42]. As expected, maternal MET supplementation increased the average methylation rate on the jejunum Pept1 promoter region in newborn pigs. Among the $25 \mathrm{CpG}$ sites tested on the Pept1 promoter region, the methylation rate of eight $\mathrm{CpG}$ sites was significantly influenced by MET. The increased CPG site -721 was located in the transcription factor CREB binding sites; CpG sites -1544 and -93 were located in the transcription factor SP1 binding sites. Research has suggested that Pept1 gene expression is mainly regulated by some transcription factor, such as caudal-related homeobox 2 (CDX2), CREB, amino acid response element (AARE) and SP1 [43]. Recently, genomic DNA methylation and transcriptome has shown a positive correlation of gene expression and methylation levels at some special genes' promoter which was not located in CGI regions [44]. The transcription factor which was sensitive to methyl directly bound to the methylated CpG region to promote gene transcription when the methylation level of the low-density $\mathrm{CpG}$ region was increased. The transcription factor which was not sensitive to methyl as a leading transcription factor specifically bound to the methylated $\mathrm{CpG}$ region to promote the binding between the downstream methylation-sensitive transcript factor and this region, finally resulting in the transcript and expression. This study's results were in agreement with studies on mice with maternal diets containing much higher amounts of methyl donors. Diets high in methyl donors promoted DNA hypermethylation and led to long-term changes in gene expression and altered phenotypes in the offspring [16].

DNA methylation occurs within the one-carbon metabolism pathway, which is dependent upon several important enzymes. Through an ATP-driven reaction with methionine adenosyltransferase (MAT), a carbon product, methionine, whose methyl groups are derived either from the folate/vitamin B12 pathway or choline/betaine pathway is converted into S-adenosylmethionine (SAM), the cellular direct methyl donor [45]. Then, DNA methyltransferases (DNMTs) covalently attach methyl groups from SAM to the carbon-5 position of cytosine bases, generating 5-methylcytosine, thus methylating DNA [42]. MTHFR and MS are key enzymes in the folate/vitamin B12 pathway and BHMT in the choline/betaine pathway [46]. Therefore, the up-regulation of jejunum DNMT1, DNMT3a, and MTHFR genes in MET newborn pigs in this study further confirmed that the higher Pept1 genes expression might be related to DNA methylation. These results suggested that maternal MET supplementation could promote offspring's intestinal digestion and absorption function by improving intestinal morphology, increasing disaccharidase activity, and up-regulating the expression of the transporter gene via methylation changes.

It is noteworthy that intestinal morphology, disaccharidase activity and nutrient transporters gene expression in offspring were significantly influenced by the interaction of maternal BPA and MET treatment. Compared with the BPA group, the ratio of jejunum villus height to crypt depth in offspring, the jejunum lactase activity in newborns, the duodenum sucrose activity in weaning pigs, and the 
Pept1 gene expression in offspring of the BPA + MET group were significantly higher. This indicates that MET could counteract the negative effects of BPA on intestinal digestion and absorption function. Moreover, these consequences could still persist until weaning, even if administration was not implemented during lactation. One possible reasonable explanation is epigenetic change, most likely DNA methylation according to a previous study on BPA or MET [8]. Once DNA methylation patterning is established, which can be stably inherited throughout the life course. The average methylation of CpG sites at the jejunum Pept1 promoter was significantly increased in the BPA + MET group. However, the specific mechanism by which MET interacts with BPA through the DNA methylation pathway requires further study.

\section{Conclusions}

In conclusion, the results of this study indicated that maternal BPA supplementation during gestation might suppress offspring intestinal digestion and absorption function, and MET could counteract the damage, which might be related to the DNA methylation status of specific genes.

Supplementary Materials: The following are available online at www.mdpi.com/2072-6643/9/5/423/s1, Table S1: Effect of maternal methyl donor or bisphenol A supplementation during gestation on body weight in newborn and weaning pigs.

Acknowledgments: The present study was supported by National Key Technology Support Program (2012BAD39B01), the Academy of Kechuang Feed Industry in Sichuan (2013NZ0056), and the Program for Changjiang Scholars and Innovative Research Team in University (IRT13083).

Author Contributions: Hong Liu, Jun Wang and De Wu conceived of and designed the experiments. Hong Liu, Jun Wang and Daolin Mou performed the experiments. Hong Liu analyzed the data. Hong Liu, Jun Wang, Daolin Mou, Lianqiang Che, Zhengfeng Fang, Bin Feng, Yan Lin, Shengyu Xu, Jian Li and De Wu contributed to the experimental analysis and discussion. Hong Liu wrote the paper.

Conflicts of Interest: The authors declare no conflicts of interest.

\section{References}

1. Brede, C.; Fjeldal, P.; Skjevrak, I.; Herikstad, H. Increased migration levels of bisphenol A from polycarbonate baby bottles after dishwashing, boiling and brushing. Food Addit. Contam. 2003, 20, 684-689. [CrossRef] [PubMed]

2. Brotons, J.A.; Olea-Serrano, M.F.; Villalobos, M.; Pedraza, V.; Olea, N. Xenoestrogens released from lacquer coatings in food cans. Environ. Health Perspect. 1995, 103, 608. [CrossRef] [PubMed]

3. Crain, D.A.; Eriksen, M.; Iguchi, T.; Jobling, S.; Laufer, H.; LeBlanc, G.A.; Guillette, L.J., Jr. An ecological assessment of bisphenol-A: Evidence from comparative biology. Reprod. Toxicol. 2007, 24, 225-239. [CrossRef] [PubMed]

4. Schönfelder, G.; Wittfoht, W.; Hopp, H.; Talsness, C.E.; Paul, M.; Chahoud, I. Parent bisphenol A accumulation in the human maternal-fetal-placental unit. Environ. Health Perspect. 2002, 110, A703. [CrossRef] [PubMed]

5. Yan, H.; Takamoto, M.; Sugane, K. Exposure to bisphenol A prenatally or in adulthood promotes TH2 cytokine production associated with reduction of CD4+CD25+ regulatory T cells. Environ. Health Perspect. 2008, 116, 514. [CrossRef] [PubMed]

6. Rubin, B.S. Bisphenol a: An endocrine disruptor with widespread exposure and multiple effects. J. Steroid Biochem. Mol. Biol. 2011, 127, 27-34. [CrossRef] [PubMed]

7. Ma, Y.; Xia, W.; Wang, D.Q.; Wan, Y.J.; Xu, B.; Chen, X.; Li, Y.Y.; Xu, S.Q. Hepatic DNA methylation modifications in early development of rats resulting from perinatal BPA exposure contribute to insulin resistance in adulthood. Diabetologia 2013, 56, 2059-2067. [CrossRef] [PubMed]

8. Kundakovica, M.; Gudsnuka, M.K.; Franksa, B.; Madrida, J.; Millerb, R.L.; Pererab, F.P.; Champagnea, F.A. Sex-specific epigenetic disruption and behavioral changes following low-dose in utero bisphenol A exposure. Proc. Natl. Acad. Sci. USA 2013, 110, 9956-9961. [CrossRef] [PubMed]

9. Dolinoy, D.C.; Huang, D.; Jirtle, R.L. Maternal nutrient supplementation counteracts bisphenol A-induced DNA hypomethylation in early development. Proc. Natl. Acad. Sci. USA 2007, 104, 13056-13061. [CrossRef] [PubMed] 
10. Nakamura, K.; Itoh, K.; Yaoi, T.; Fujiwara, Y.; Sugimoto, T.; Fushiki, S. Murine neocortical histogenesis is perturbed by prenatal exposure to low doses of bisphenol A. J. Neurosci. Res. 2006, 84, 1197-1205. [CrossRef] [PubMed]

11. Flint, S.; Markle, T.; Thompson, S.; Wallace, E. Bisphenol A exposure, effects, and policy: A wildlife perspective. J. Environ. Manag. 2012, 104, 19-34. [CrossRef] [PubMed]

12. Bromer, J.G.; Zhou, Y.; Taylor, M.B.; Doherty, L.; Taylor, H.S. Bisphenol-A exposure in utero leads to epigenetic alterations in the developmental programming of uterine estrogen response. FASEB J. 2010, 24, 2273-2280. [CrossRef] [PubMed]

13. Jirtle, R.L.; Skinner, M.K. Environmental epigenomics and disease susceptibility. Nat. Rev. Genet. 2007, 8, 253-262. [CrossRef] [PubMed]

14. Waterland, R.A.; Jirtle, R.L. Transposable elements: Targets for early nutritional effects on epigenetic gene regulation. Mol. Cell. Biol. 2003, 23, 5293-5300. [CrossRef] [PubMed]

15. Cropley, J.E.; Suter, C.M.; Beckman, K.B.; Martin, D.I. Germ-line epigenetic modification of the murine Avy allele by nutritional supplementation. Proc. Natl. Acad. Sci. USA 2006, 103, 17308-17312. [CrossRef] [PubMed]

16. Waterland, R.A.; Travisano, M.; Tahiliani, K.G. Diet-induced hypermethylation at agouti viable yellow is not inherited transgenerationally through the female. FASEB J. Off. Publ. Federation Am. Soc. Exp. Biol. 2007, 21, 3380-3385. [CrossRef] [PubMed]

17. Matte, J.J.; Girard, C.L.; Brisson, G.J. The role of folic acid in the nutrition of gestating and lactating primiparous sows. Livest. Prod. Sci. 1992, 32, 131-148. [CrossRef]

18. van Wettere, W.H.E.J.; Herde, P.; Hughes, P.E. Supplementing sow gestation diets with betaine during summer increases litter size of sows with greater numbers of parities. Anim. Reprod. Sci. 2012, 132, 44-49. [CrossRef] [PubMed]

19. Kornegay, E.; Meacham, T. Evaluation of supplemental choline for reproducing sows housed in total confinement on concrete or in dirt lots. J. Anim. Sci. 1973, 37, 506-509. [CrossRef] [PubMed]

20. Stockland, W.; Blaylock, L. Choline requirement of pregnant sows and gilts under restricted feeding conditions. J. Anim. Sci. 1974, 39, 1113-1116. [CrossRef] [PubMed]

21. Matte, J.; Guay, F.; Girard, C. Folic acid and vitamin B12 in reproducing sows: New concepts. Can. J. Anim. Sci. 2006, 86, 197-205. [CrossRef]

22. Li, G.; Chang, H.; Xia, W.; Mao, Z.; Li, Y.; Xu, S. F0 maternal BPA exposure induced glucose intolerance of F2 generation through DNA methylation change in Gck. Toxicol. Lett. 2014, 228, 192-199. [CrossRef] [PubMed]

23. Pluske, J.; Williams, I.; Aherne, F. Maintenance of villous height and crypt depth in piglets by providing continuous nutrition after weaning. Anim. Sci. 1996, 62, 131-144. [CrossRef]

24. Mariadason, J.M.; Nicholas, C.; Kaitlin, E.; Zhuang, M.; Smartt, H.J.; Heerdt, B.G.; Yang, W.; Corner, G.A.; Wilson, A.J.; Klampfer, L. Gene expression profiling of intestinal epithelial cell maturation along the crypt-villus axis. Gastroenterology 2005, 128, 1081-1088. [CrossRef] [PubMed]

25. Alizadeh, M.; Ota, F.; Hosoi, K.; Kato, M.; Sakai, T.; Satter, M.A. Altered allergic cytokine and antibody response in mice treated with bisphenol A. J. Med. Investig. 2006, 53, 70-80. [CrossRef]

26. Goto, M.; Takano-Ishikawa, Y.; Ono, H.; Yoshida, M.; Yamaki, K.; Shinmoto, H. Orally administered bisphenol A disturbed antigen specific immunoresponses in the naive condition. Biosci. Biotechnol. Biochem. 2007, 71, 2136-2143. [CrossRef] [PubMed]

27. Kagnoff, M.F. Mucosal immunology: New frontiers. Immunol. Today 1996, 17, 57-59. [CrossRef]

28. Iwanaga, T. The involvement of macrophages and lymphocytes in the apoptosis of enterocytes. Arch. Histol. Cytol. 1995, 58, 151-159. [CrossRef] [PubMed]

29. Zasloff, M. Antimicrobial peptides of multicellular organisms. Nature 2002, 415, 389-395. [CrossRef] [PubMed]

30. Henning, S.J. Ontogeny of enzymes in the small intestine. Ann. Rev. Physiol. 1985, 47, 231-245. [CrossRef] [PubMed]

31. Mickiewicz, M.; Zabielski, R.; Grenier, B.; Le Normand, L.; Savary, G.; Holst, J.J.; Oswald, I.P.; Metges, C.C.; Guilloteau, P. Steuctural and functional development of small intestine in inteauterin growth retarded porcine offspring born to gilts fed diet with differing protein ratios throughout pregnancy. J. Physiol. Pharmacol. 2012, 63, 225-239. [PubMed] 
32. Osswald, C.; Baumgarten, K.; Stumpel, F.; Gorboulev, V.; Akimjanova, M.; Knobeloch, K.P.; Horak, I.; Kluge, R.; Joost, H.G.; Koepsell, H. Mice without the regulator gene Rsc1A1 exhibit increased Na+-D-glucose cotransport in small intestine and develop obesity. Mol. Biol. Cell 2005, 25, 78-87. [CrossRef] [PubMed]

33. Daniel, H. Molecular and integrative physiology of intestinal peptide transport. Annu. Rev. Physiol. 2004, 66, 361-384. [CrossRef] [PubMed]

34. Erickson, R.H.; Gum, J.R.; Lindstrom, M.M.; McKean, D.; Kim, Y.S. Regional expression and dietary regulation of rat small intestinal peptide and amino acid transporter mRNAs. Biochem. Biophys. Res. Commun. 1995, 216, 249-257. [CrossRef] [PubMed]

35. Smith, C.C.; Taylor, H.S. Xenoestrogen exposure imprints expression of genes (Hoxa10) required for normal uterine development. FASEB J. 2007, 21, 239-246. [CrossRef] [PubMed]

36. Dalmasso, G.; Nguyen, H.T.T.; Yan, Y.; Charrier-Hisamuddin, L.; Sitaraman, S.V.; Merlin, D. Butyrate transcriptionally enhances peptide transporter PepT1 expression and activity. PLoS ONE 2008, 3, e2476. [CrossRef] [PubMed]

37. Shimakura, J.; Terada, T.; Katsura, T.; Inui, K. Characterization of the human peptide transporter PEPT1 promoter: Sp1 functions as a basal transcriptional regulator of human PEPT1. Am. J. Physiol. Gastrointest. Liver Physiol. 2005, 289, G471-G477. [CrossRef] [PubMed]

38. Deaton, A.M.; Bird, A. CpG islands and the regulation of transcription. Genes Dev. 2011, 25, 1010-1022. [CrossRef] [PubMed]

39. Okano, M.; Bell, D.W.; Haber, D.A.; Li, E. DNA methyltransferases Dnmt3a and Dnmt3b are essential for de novo methylation and mammalian development. Cell 1999, 99, 247-257. [CrossRef]

40. Kundakovic, M.; Champagne, F.A. Epigenetic perspective on the developmental effects of bisphenol A. Brain Behav. Immun. 2011, 25, 1084-1093. [CrossRef] [PubMed]

41. Bressenot, A.; Pooya, S.; Bossenmeyer-Pourie, C.; Gauchotte, G.; Germain, A.; Chevaux, J.B.; Coste, F.; Vignaud, J.M.; Gueant, J.L.; Peyrin-Biroulet, L. Methyl donor deficiency affects small-intestinal differentiation and barrier function in rats. Br. J. Nutr. 2013, 109, 667-677. [CrossRef] [PubMed]

42. Anderson, O.S.; Sant, K.E.; Dolinoy, D.C. Nutrition and epigenetics: An interplay of dietary methyl donors, one-carbon metabolism and DNA methylation. J. Nutr. Biochem. 2012, 23, 853-859. [CrossRef] [PubMed]

43. Fei, Y.J.; Sugawara, M.; Liu, J.C.; Li, H.W.; Ganapathy, V.; Ganapathy, M.E.; Leibach, F.H. cDNA structure, genomic organization, and promoter analysis of the mouse intestinal peptide transporter PEPT1. Biochim. Biophys. Acta 2000, 1492, 145-154. [CrossRef]

44. Schubeler, D. Function and information content of DNA methylation. Nature 2015, 517, 321-326. [CrossRef] [PubMed]

45. Selhub, J. Homocysteine metabolism. Ann. Rev. Nutr. 1999, 19, 217-246. [CrossRef] [PubMed]

46. Jacques, P.F.; Bostom, A.G.; Williams, R.R.; Ellison, R.C.; Eckfeldt, J.H.; Rosenberg, I.H.; Selhub, J.; Rozen, R. Relation between folate status, a common mutation in methylenetetrahydrofolate reductase, and plasma homocysteine concentrations. Circulation 1996, 93, 7-9. [CrossRef] [PubMed]

(C) 2017 by the authors. Licensee MDPI, Basel, Switzerland. This article is an open access article distributed under the terms and conditions of the Creative Commons Attribution (CC BY) license (http:/ / creativecommons.org/licenses/by/4.0/). 